\title{
Interactions between ungulates, forests, and supplementary feeding: the role of nutritional balancing in determining outcomes
}

\author{
Annika M. Felton ${ }^{1} \cdot$ Adam Felton $^{1}$ (D) - Joris P. G. M. Cromsigt ${ }^{2,3} \cdot$ Lars Edenius $^{2}$ • \\ Jonas Malmsten ${ }^{4} \cdot$ Hilde Karine Wam ${ }^{5}$
}

Received: 18 May 2016/Accepted: 16 November 2016/Published online: 25 November 2016

(C) The Author(s) 2016. This article is published with open access at Springerlink.com

\begin{abstract}
People provide wild ungulates with large quantities of supplementary feed to improve their health and survival and reduce forest damage. Whereas supplementary feeding can positively affect the winter survival of ungulates and short-term hunting success, some of the feeds provided may actually reduce ungulate health and increase forest damage. Here, we highlight how recent advances in ungulate nutritional ecology can help explain why supplementary feeding can lead to undesirable outcomes. Using Europe's largest cervid, the moose (Alces alces), as a model species, and Sweden, as the socio-ecological context, we explain the concept of nutritional balancing and its relevance to supplementary feeding. Nutritional balancing refers to how animals alter their food intake to achieve a specific nutritional target balance in their diet, by selecting balanced food items or by combining items with nutritional compositions that are complimentary. As the most common supplementary feeds used contain higher concentrations of non-structural carbohydrates than the
\end{abstract}

Communicated by: Rafał Kowalczyk

Annika M. Felton

annika.felton@slu.se

1 Southern Swedish Forest Research Centre, Swedish University of Agricultural Sciences (SLU), PO Box 49, 23053 Alnarp, Sweden

2 Department of Wildlife, Fish and Environmental Studies, Swedish University of Agricultural Sciences (SLU), 90183 Umeå, Sweden

3 Department of Zoology, Centre for African Conservation Ecology, Nelson Mandela Metropolitan University, PO Box 77000, Port Elizabeth, South Africa

4 Wildlife Consultant Ltd, Mörbytorpsv. 303, 186 94 Vallentuna, Sweden

5 Division for Forestry and Forest Resources, Norwegian Institute of Bioeconomy Research (NIBIO), PO Box 115, 1431 Ås, Norway ungulates' normal winter diet, the consumption of such feeds may cause animals to increase their intake of woody browse, and thereby exacerbate forest damage. We also explain how animal health may be negatively affected by large intakes of such feed if complementary browse items are not available. We therefore suggest that the use of inappropriate feed is an additional means by which supplementary feeding may result in negative outcomes for hunters, forest owners, and wild animals.

Keywords Sweden $\cdot$ Alces alces $\cdot$ Moose $\cdot$ Supplementary feeding $\cdot$ Browsing $\cdot$ Forest damage $\cdot$ Animal health $\cdot$ Wildlife

\section{Introduction}

Supplementary feeding involves the deliberate placement of food into the environment with the aim of regulating the availability of food sources for wild animal species (Sorensen et al. 2014). Supplementary feeding can be used to enhance an animal's winter survival (Doenier et al. 1997) and reproductive success (Robb et al. 2008), to create aggregations of individuals for the benefit of hunting and tourism (Geisser et al. 2004; Orams 2002), to manipulate migration routes (Sahlsten et al. 2010), and to divert animals away (viz. diversionary feeding) from roads and other potential human-wildlife conflict areas (Andreassen et al. 2005). An important example of this diversion strategy is the use of supplementary feeding to reduce damage by ungulates to forests and crops (van Beest et al. 2010b), based on the assumption that one bite of supplementary feed results in one less bite in the forest or field.

It is not unusual, however, that supplementary feeding regimes fail to achieve the intended goals, or that they result in additional unforeseen problems (Milner et al. 2014). For example, supplementary feeding may increase disease transmission 
(Sorensen et al. 2014), as well as unintentionally alter the demography (Ballesteros et al. 2013), behavior (Forristal et al. 2012), and population genetics (Blanchong et al. 2006) of the targeted game species, sometimes with cascading effects on vegetation (Rinella et al. 2012) and other fauna (Mathisen et al. 2012; Mathisen and Skarpe 2011). Furthermore, although exceptions occur, supplementary feeding rarely appears to be effective at actually reducing browsing-related damage to crops, production forests, or natural habitats (Cooper et al. 2006; Doenier et al. 1997; van Beest et al. 2010b).

In this perspective piece, we highlight how recent advances in our understanding of the nutritional ecology of wild animals can help to explain at least some of the reasons supplementary feeding can lead to unintended and undesired outcomes. Using Europe's largest free-ranging cervid, the moose (Alces alces), as a model species, and conducting our evaluation within the Swedish context, we explain the concept of nutritional balancing and its relevance to supplementary feeding. Furthermore, we raise the potential for a "lose-lose" outcome to arise for hunters, forest owners, and wild forest-dwelling ungulates due specifically to the widespread provision of "the wrong" feeds. Throughout, we link the Swedish context to studies elsewhere to show how the concepts we introduced are highly applicable for the co-management of wildlife and forestry across the northern hemisphere.

\section{Background to the moose and nutritional balancing}

As a specialized browser, the preferred diet of moose throughout the growth season consists of selected green plant material, including the leaves of deciduous trees, shrubs, and herbs (Cederlund et al. 1980; Månsson et al. 2007; Rea et al. 2014; Wam and Hjeljord 2010). During leaf-fall in the autumn, moose adjust their rumen physiology, metabolism, and food intake rates to adapt to a relatively nutrient poor and ligninrich winter diet of twigs and conifer needles (Hofmann 1989; Regelin et al. 1985; Schwartz et al. 1988). With respect to their nutritional ecology, recent experimental evidence (Felton et al. 2016c) indicates that moose engage in nutritional balancing. Nutritional balancing is found in an increasingly diverse group of animals and involves the altering of food intake on a daily or near daily basis to achieve a specific nutritional target balance in the diet, either by selecting nutritionally balanced food items or by combining food items with compositions complimentary to each other (e.g., Felton et al. 2009; Mayntz et al. 2009; Rothman et al. 2011; Simpson and Raubenheimer 2012). This regulatory feat is explained by several neural and chemical processes and feedbacks operating before, during, and after digestion (Berteaux et al. 1998; Provenza 1995).

Specifically, the controlled feeding experiment conducted by Felton et al. (2016c) demonstrated that when moose are given free choice, individuals consumed food items in a manner which targeted a particular dietary balance between protein and carbohydrates (Fig. 1). Furthermore, when restricted to one of two nutrient-rich but imbalanced pelleted diets, which provided either too much or too little protein or carbohydrates compared to the moose' target balance, individuals tried to compensate for this imbalance by increasing their consumption of twigs from the broadleaf branches provided. This compensatory feeding response was not due to any deficiencies of single nutrients (the pellets contained more than the minimum requirements of all macronutrient and micronutrients for moose), but rather appears to have resulted from the short-term imbalanced nutritional state the moose were forced into when not given free choice between pellet types. Consistent with this explanation, the twigs were found to have a nutritional composition very similar to the nutritional target balance identified during the experiment (Fig. 1).

Studies from around the northern hemisphere and on a diversity of ungulate species lend additional weight to the importance of dietary mixing (Beck and Peek 2005; Berteaux et al. 1998; Oldemeyer et al. 1977; Parsons et al. 1994; Westoby 1974). More specifically, there are many indications of compensatory feeding responses by supplementary fed wild ungulates: for example, if white-tailed deer (Odocoileus virginiatus) are provided with ad libitum access of energy dense food (corn, oats, or pellets), they continue (Cooper et al. 2006; Doenier et al. 1997; Schmitz 1990) or even double their normal intake of browse (Timmons et al. 2010). Also, red deer (Cervus elaphus), provided with nutrient-rich supplementary feed, have been found to increase their intake of certain species of woody vegetation which complement the nutritional composition of the supplementary food items (Miranda et al. 2015). The process of nutritional balancing and compensatory feeding is therefore likely to be of relevance to the understanding and effective management of other socio-ecological systems involving various ungulate species, supplementary feeds, and geographical contexts.

\section{The Swedish context: forest management and supplementary feeding}

Productive forests cover approximately $60 \%$ of land area in Sweden, and the vast majority is used for the production of timber and other wood products (SFA 2014). Forestry in Sweden is primarily conducted using the even-aged management of conifer-dominated stands. This model of forest management dominates the structure and dynamics of forested landscapes in much of northern Europe (Kuuluvainen 2009). Over the last hundred years, clear-cutting and other anthropogenic forms of land-use change have dramatically altered tree species composition in Sweden, largely to the detriment of broadleaf and mixed forest cover (Edenius et al. 2002; 


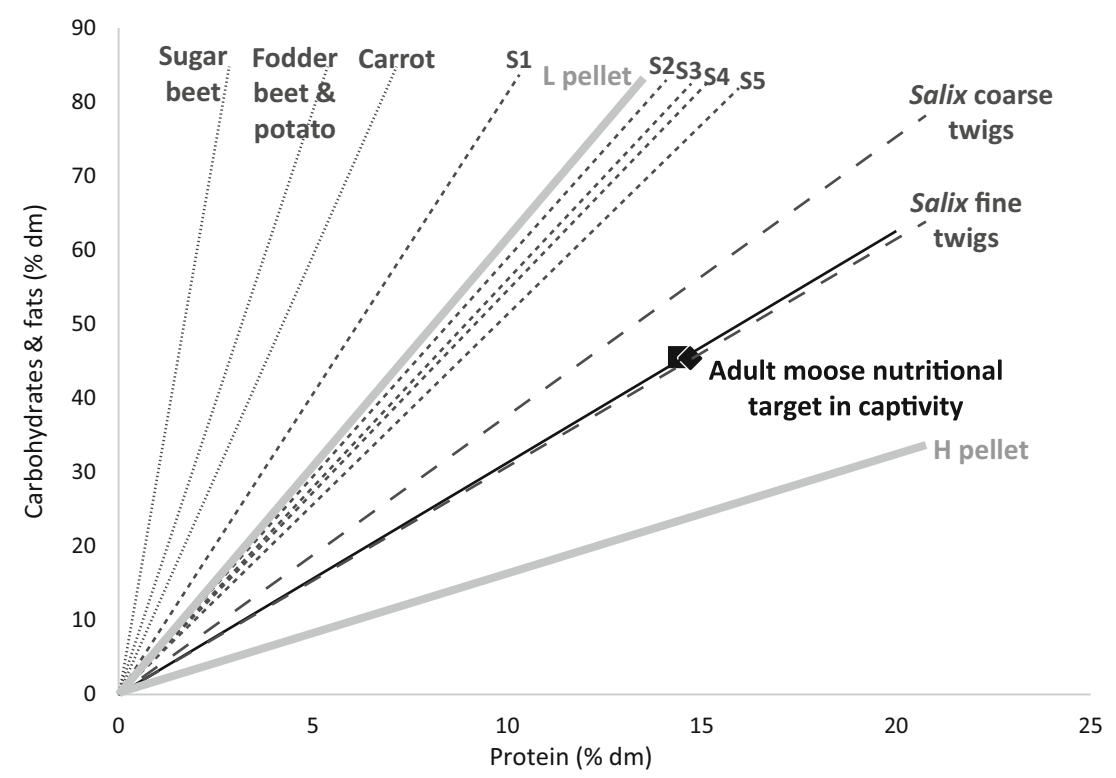

Fig. 1 The macro-nutritional balance of the most commonly used supplementary feeds in Sweden (root vegetables and silages (S1-S5)) in relation to twigs of Salix, a tree genus commonly consumed by moose during winter. All dashed radials ("food rails") represent the nutritional balance of food items: the more an individual eats of an item, the further along the rail they shift. Also indicated is the nutritional target balance of adult moose ( square $=$ females, diamond $=$ males), as experimentally determined in captivity (Felton et al. 2016c), with the solid black line showing the associated intake trajectory. Free-ranging moose may differ somewhat in this target balance. In the experiment, moose that were restricted to one of two pelleted diets that in isolation was imbalanced for them (either $\mathrm{L}=$ low-protein, high-carbohydrate; or $\mathrm{H}=$ high-protein, low carbohydrate; thick light gray lines) responded by significantly increasing their intake of Salix twigs which were offered to them in limited amounts (S. caprea, S. fragilis, and S. cinerea; mean compositions indicated by gray lines, large dashes). Note that most

Lindbladh et al. 2014). Norway spruce (Picea abies) has benefited most from such changes, to the extent that in southern Sweden, spruce-dominated production stands now comprise $40 \%$ of forest area (Drössler 2010). This form of forest management has direct implications for ungulate food resources (Kuijper 2011). Ungulates in Sweden generally prefer to browse on Scots pine (Pinus sylvestris) and deciduous species (such as rowan (Sorbus aucuparia), aspen (Populus tremula), and birch (Betula spp.)) rather than Norway spruce (Mansson et al. 2007), and the dominance of Norway spruce production forests reduces the availability of these primary food sources. Partly countering these losses, the predominance of even-aged forest management ensures that a flush of edible vegetation is provided, at least in unfenced stands, for the first decade after clear-cutting (Wam et al. 2016). However, efforts to remove competing broadleaf tree species (predominantly birch) during stand cleaning and thinning operations reduce the potential availability of these preferred species of browse, even in young stands (Milner et al. 2013).

During winter in Sweden, and throughout Scandinavia, many land owners and game managers place supplementary supplementary feeds characteristically have a lower non-protein balance than the twig material, and thereby are inconsistent with the moose's nutritional target. Root vegetables (gray lines, small dashes) include sugar and fodder beet (varieties of B. vulgaris), potato (Solanum tuberosum), and carrot (Daucus carota sativus). Silages (gray lines, medium dashes) include whole sweet corn plants (S1), graminoid mix with $<25 \%$ legumes (S2), whole oat plants (S3), whole barley plants (S4), and graminoid mix with 25-50\% legumes (S5). Included are estimates of the protein that is available to ruminants for digestion ( $x$-axis) and the sum of fats, non-structural carbohydrates, and fractions of structural carbohydrates (fiber) that are digestible by ruminants ( $y$-axis). Supplementary feed data are found in Spörndly (2003) in which digestibility estimates are made for dairy cows. Data on Salix, pellets, and moose nutritional target are sourced from Felton et al. (2016c) in which digestibility estimates are made for moose.

feed in the landscape, often targeting wild ruminants such as moose, roe deer (Capreolus capreolus), red deer (C. elaphus), and fallow deer (Dama dama) (the non-ruminant wild boar, Sus scrofa, is also a targeted ungulate species but is not discussed here) (SOU 2014). The extent of this feeding is significant: in 2013, it was estimated that at least 350 million SEK worth of feed (approx. 42 Million USD) was provided to wild animals in Sweden (SOU 2014). Silage bales are the most common type of feed (SOU 2014) and consist of various graminoids and herbs. The nutritional composition of such silages varies, but typically has higher contents of starch and other non-structural carbohydrates than woody browse (Fig. 1). Some of these silages may be suitable forages for fallow deer and red deer, whose dietary niche is intermediate between that of browsers and grazers (Clauss et al. 2009; Hofmann 1989).

It is also common in Sweden to feed game with agricultural crops that are even richer in sugar and starch than silage. In southern Sweden in particular, sugar and fodder beets (varieties of Beta vulgaris), potatoes, and other root vegetables are often placed in large piles in the rural landscape during winter 
months. Indeed, sugar beet is the second most commonly used supplementary feed in Sweden, and it is estimated that at least 32,400 tons of beets are provided to game animals every year in the southern parts of the country (SOU 2014). A pilot study showed that during three winter months in some local hunting areas, as much as 2 tons of supplementary feed $/ \mathrm{km}^{2}$ are distributed, of which approximately $40 \%$ is made up of beets and other root vegetables (Blomqvist 2016). Such crops have been cultivated for enhanced energy content and have nutritional compositions that are highly inconsistent with the natural winter diet of moose (Fig. 1). Nevertheless, moose do consume these feeds, whether or not they were the intended recipient (unpublished data of rumen contents, A.M. Felton).

\section{Implications for ungulate health and competitive interactions among species}

Because the supplementary feeds commonly used in Scandinavia contain higher concentrations of non-structural carbohydrates than the natural winter diet of ungulates, this practice raises some specific animal health concerns. In addition to concerns regarding their dental health (Malmsten et al. 2015), a large intake of such foods by a ruminant during winter is inconsistent with their rumen flora and metabolism, which is adapted to woody, lignin-rich foods (Schwartz et al. 1988). Resultant problems are likely to arise if complementary food items, such as young broadleaf tree species or Scots pine in the case of the moose, are not available or consumed in sufficient amounts to ameliorate a dietary imbalance (as indicated by experiments with other species of ruminants, Keunen et al. 2002; Timmons et al. 2010). As a result, rumen $\mathrm{pH}$ can decline, which increases the risk of ruminal acidosis. Ruminal acidosis is a suspected cause of serious health problems in both captive moose (Mueller et al. 2011; Shochat et al. 1997) and in free-ranging moose forced to persist on crops (Butler et al. 2008). Depending on the severity and time span, ruminal acidosis can lead to impaired digestion, poor general condition, vitamin deficiency, laminitis, and death (M.V. M 2005). Ruminal acidosis can also be indirectly harmful to unweaned young ruminants (M.V. M 2005), which suffer due to the accompanying reduction in the fat concentration of their mother's milk (Allen 1997; Keunen et al. 2002). Due to the potential impacts on their rumen and dental status, root vegetables rich in sugar and starch are unlikely to be suitable feeds for any of the wild ruminants, but further research is needed to determine whether this expectation may be qualified.

Supplementary feeding is also likely to lead to populationand community level impacts that are potentially counterproductive to the aims of game management (Putman and Staines 2004). As previously noted, some ungulate species appear to benefit more from certain types of supplementary feeding than others. For example, a study has shown that silage offered during winter time in a region of southern Sweden was utilized to a higher extent by fallow deer than by moose, relative to their respective population sizes (Otto 2013). Supplementary feeding is thereby likely to maintain fallow deer at much higher densities in these areas than would otherwise occur. Although the effects of supplementary feeding on the community ecology of ungulates is poorly understood, increased fallow deer densities are likely to increase competitive pressures on other ungulate species, including the moose, particularly during spring and summer when species overlap in their resource use. Moreover, from studies elsewhere in Europe, fallow deer is known to displace other species from feeding sites, such as roe deer (Ferretti et al. 2008) and red deer (Bartoš et al. 1996).

\section{Implications for forest management}

Ungulates and forestry interact in varied and complex ways. Browsers affect forestry by damaging production trees, and forestry affects ungulates by changing tree composition and age structure of the forest landscape (Wam et al. in press), with associated implications for food and shelter availability (Kuijper 2011; Kuijper et al. 2009; Milner et al. 2013). The potential influence of supplementary feeding on ungulate browsing behavior and community composition adds to this complex web of interactions.

Multiple studies challenge the use of supplementary feeding as an effective means of reducing the intake of browse by ungulates during winter, and thereby as a way to reduce forest damage (Milner et al. 2014). In Scandinavia, extensive forest damage can occur within a kilometer of feeding stations (Gundersen et al. 2004; van Beest et al. 2010a) and at larger landscape scales (Mathisen et al. 2014). Such high damage levels are often explained by the proximity of feeding sites to forest stands, the longevity of the feeding program, and the associated increase in ungulate densities (Milner et al. 2014). The recent finding that captive moose show compensatory feeding when given inappropriate high-energy or highprotein foods (Felton et al. 2016c), and similar observations in other ungulate study systems (Cooper et al. 2006; Doenier et al. 1997; Miranda et al. 2015; Schmitz 1990; Timmons et al. 2010), suggests that the nutritional composition of supplementary feed can influence and may even exacerbate the levels of damage incurred.

With respect to the trees' vulnerability to browsing, Scots pine and some broadleaved species are able to maintain or even increase shoot biomass if subjected to repeated browsing pressure at low to moderate levels during the winter, particularly when growing on productive soils (Edenius 1993; Persson et al. 2005). However, if an individual tree is in a state proximate to a physiological threshold, even a small increase 
in browsing intensity could have significant effects on a tree's growth characteristics and the quality of its timber (Bergqvist et al. 2013; Edenius et al. 2002). For this reason, the cumulative effects on forests of the extensive provision of potentially nutritionally imbalanced feed for ungulates require further consideration.

Increased browsing damage is also influencing the longterm management trajectory of forests, with resultant repercussions for wild ungulates and forest biodiversity in general. This is because the severity of browsing damage within a region has a strong influence on forest owner decisions regarding which tree species to use for regeneration. If the level of browsing damage is sufficiently high, or perceived to be problematic, Norway spruce is currently favored at the expense of other production forest alternatives, including broadleaf tree species and Scots pine (Lidskog and Sjödin 2014), with negative implications for biodiversity and forest resilience (Felton et al. 2016a; Felton et al. 2016b). This can readily create a feedback loop, in which the resultant intensified browsing damage in the remaining pine and deciduous forest areas (Herfindal et al. 2015) provides further motivation for the increased use of Norway spruce in production forests. The extent to which supplementary feeding influences this feedback loop needs to be addressed.

\section{Conclusion}

Our understanding of the nutritional ecology of forest ungulates is sufficient to challenge the view that management goals for forests and game are likely to be achieved using many of the current approaches to supplementary feeding. For this reason, it is in the direct interest of game and forest managers to be aware of the potential adverse consequences of using inappropriate supplementary feeds. Notably, in recent years, the reproductive performance of many moose populations in southern Scandinavia appears to be in decline (Wam et al. 2016). While the precise causal factors underlying these trends remain unaccounted for, the available evidence suggests that in some areas, inappropriate supplementary feeding may contribute to the problem, via for example, negative effects on their rumen condition and increased competition from other ungulate species. We suggest that if the supplementary feeding of browsing ungulates is to take place, suitable feed alternatives are items that resemble the animals' natural diets, such as residue material from timber extraction and stand thinning (e.g., tree tops, Edenius et al. 2014; Heikkilä and Härkönen 2000), or bales made of fast-growing broadleaves (Otto 2013 and unpublished data, A.M. Felton).

The use of nutritionally balanced food items is not, however, a panacea for all the problems associated with supplementary feeding. For example, even if supplementary feed is nutritionally balanced, the mere act of feeding can increase animal aggregation and thereby increase local forest damage or disease transmission among ungulate populations (Sorensen et al. 2014). If the preferred option is to retain animal densities, the larger question must therefore be raised as to what alternatives are available or even preferable to supplementary feeding. With respect to alleviating forest damage, plausible alternatives involve increasing the amount of natural browse at larger spatial scales to minimize the contrast in food availability between regenerating stands and the surrounding mature forest (Kuijper et al. 2009; Milner et al. 2013), and thereby decrease the browsing damage burden on any one forest owner (Heikkilä and Härkönen 1996; Herfindal et al. 2015; Månsson 2007). For example, due to the concerted effort of a large number of private forest owners in one region of southern Sweden, the planting of Scot's pine has increased significantly in recent years, resulting in lower rates of forest damage and less conflict between hunters and forest owners (pers. comm. Ove Andersson, Swedish Forest Agency). It is also possible that the pre-commercial thinning of production forests could be altered to help preserve and promote the growth of edible biomass throughout the forest landscape (Edenius et al. 2014). To alleviate the browsing damage caused by those deer species that are intermediate feeders (e.g., red deer), creating safe grass-dominated open spaces within the forest matrix may be effective (Burkhardt 2011). Potential solutions therefore appear to be available. What is now required is that ecologists, wildlife veterinarians, and silviculturalists further investigate the links between ungulate food, animal health, and forest damage, so that mutually beneficial alternatives can be identified.

Acknowledgments AMF was funded by Stiftelsen Skogsällskapet (1011-79/150-7 HJHIL), the Swedish Environment Protection Agency (NV-01740-14), and Södra Skogsägarnas Stiftelse för Forskning, Utveckling och Utbildning. AF was funded by Future Forests, supported by the Foundation for Strategic Environmental Research (MISTRA). JPGMC was funded by the Swedish Environment Protection Agency (program Beyond Moose, NV-01337-15). We specifically thank Magnus Strandberg at Skogssällskapet.

Open Access This article is distributed under the terms of the Creative Commons Attribution 4.0 International License (http:// creativecommons.org/licenses/by/4.0/), which permits unrestricted use, distribution, and reproduction in any medium, provided you give appropriate credit to the original author(s) and the source, provide a link to the Creative Commons license, and indicate if changes were made.

\section{References}

Allen MS (1997) Relationship between fermentation acid production in the rumen and the requirement for physically effective fiber. J Dairy Sci 80:1447-1462. doi:10.3168/jds.S0022-0302 (97)76074-0

Andreassen HP, Gundersen H, Storaas T (2005) The effect of scent-marking, forest clearing, and supplemental feeding on moose-train 
collisions. J Wildlife Manage 69:1125-1132. doi:10.2193/0022-541 x(2005)069[1125:teosfc]2.0.co;2

Ballesteros M, Bardsen BJ, Fauchald P, Langeland K, Stien A, Tveraa T (2013) Combined effects of long-term feeding, population density and vegetation green-up on reindeer demography. Ecosphere 4. doi:10.1890/es13-00015.1

Bartoš L, Vaňková D, Šiler J, Losos S (1996) Fallow deer tactic to compete over food with red deer. Aggressive Behav 22:375-385. doi:10.1002/(SICI)1098-2337(1996)22:5<375::AID-AB6>3.0. $\mathrm{CO} ; 2-\mathrm{I}$

Beck JL, Peek JM (2005) Great Basin summer range forage quality: do plant nutrients meet elk requirements? West N Amer Nat 65:516527

Bergqvist G, Bergstrom R, Wallgren M (2013) Summer browsing by moose on Scots pine. Scand J For Res 28:110-116. doi:10.1080/02827581.2012.725767

Berteaux D, Crete M, Huot J, Maltais J, Ouellet JP (1998) Food choice by white-tailed deer in relation to protein and energy content of the diet: a field experiment. Oecologia 115:84-92

Blanchong JA, Scribner KT, Epperson BK, Winterstein SR (2006) Changes in artificial feeding regulations impact white-tailed deer fine-scale spatial genetic structure. J Wildlife Manage 70:10371043. doi:10.2193/0022-541x(2006)70[1037:ciafri] 2.0.co;2

Blomqvist J (2016) Stödutfodring av klövvilt i södra Sverige: en jämförelse av utfodringsintensitet, fodertyper och andra påverkande faktorer på lokal och regional nivå. Swedish University of Agricultural Sciences

Burkhardt P (2011) Ein Jahr im Rotwildrevier - Jagdpraxis und Hege. Müller Rüschlikon Verlag, Stuttgart

Butler EA, Jensen WF, Johnson RE, Scott JM (2008) Grain overload and secondary effects as potential mortality factors of moose in North Dakota. Alces 44:73-79

Cederlund G, Ljungqvist H, Markgren G, Stålfelt G (1980) Foods of moose and roe-deer at Grimsö in central Sweden: results of rumen content analyses. Swed Wildlife Res 11:171-247

Clauss M, Hofmann RR, Fickel J, Streich WJ, Hummel J (2009) The intraruminal papillation gradient in wild ruminants of different feeding types: implications for rumen physiology. J Morphol 270:929 942. doi:10.1002/jmor.10729

Cooper SM, Owens MK, Cooper RM, Ginnett TF (2006) Effect of supplemental feeding on spatial distribution and browse utilization by white-tailed deer in semi-arid rangeland. J Arid Environ 66:716726. doi:10.1016/j.jaridenv.2005.11.015

Doenier PB, DelGiudice GD, Riggs MR (1997) Effects of winter supplemental feeding on browse consumption by white-tailed deer. Wildlife Soc B 25:235-243

Drössler L (2010) Tree species mixtures-a common feature of southern Swedish forests. Forestry 83:433-441. doi:10.1093 /forestry/cpq025

Edenius L (1993) Browsing by moose on Scots pine in relations to plant resource availability. Ecology 74:2261-2269. doi:10.2307/1939579

Edenius L, Bergman M, Ericsson G, Danell K (2002) The role of moose as a disturbance factor in managed boreal forests. Silva Fennica 36: $57-67$

Edenius L, Roberge J-M, Månsson J, Ericsson G (2014) Ungulateadapted forest management: effects of slash treatment at harvest on forage availability and use. Eur J Forest Res 133:191-198. doi:10.1007/s10342-013-0758-2

Felton A et al (2016a) How climate change adaptation and mitigation strategies can threaten or enhance the biodiversity of production forests: insights from Sweden. Biol Conserv 194:11-20. doi:10.1016/j.biocon.2015.11.030

Felton A et al (2016b) Replacing monocultures with mixed-species stands: ecosystem service implications of two production forest alternatives in Sweden. Ambio 45:124-139. doi:10.1007/s13280015-0749-2
Felton AM et al (2009) Protein content of diets dictates the daily energy intake of a free-ranging primate. Behav Ecol 20:685-690. doi:10.1093/beheco/arp021

Felton AM, Felton A, Raubenheimer D, Simpson SJ, Kriszan SJ, Hedwall P-O, Stolter C (2016c) The nutritional balancing act of a large herbivore: an experiment with captive moose (Alces alces L). PLoS One 11:e0150870. doi:10.1371/journal.pone.0150870

Ferretti F, Sforzi A, Lovari S (2008) Intolerance amongst deer species at feeding: roe deer are uneasy banqueters. Behav Process 78:487491. doi:10.1016/j.beproc.2008.02.008

Forristal VE, Creel S, Taper ML, Scurlock BM, Cross PC (2012) Effects of supplemental feeding and aggregation on fecal glucocorticoid metabolite concentrations in elk. J Wildlife Manage 76:694-702. doi: $10.1002 / j w m g .312$

Geisser H, Reyer H-U, Krausman (2004) Efficacy of hunting, feeding, and fencing to reduce crop damage by wild boars. J Wildlife Manage 68:939-946. doi:10.2193/0022-541X(2004)068[0939 :EOHFAF]2.0.CO;2

Gundersen H, Andreassen HP, Storaas T (2004) Supplemental feeding of migratory moose Alces alces: forest damage at two spatial scales. Wildlife Biol 10:213-223

Heikkilä R, Härkönen S (1996) Moose browsing in young Scots pine stands in relation to forest management. For Ecol Manag 88:179 186. doi:10.1016/s0378-1127(96)03823-6

Heikkilä R, Härkönen S (2000) Thinning residues as a source of browse for moose in managed forests in Finland. Alces 36:85-92

Herfindal I, Tremblay J-P, Hester AJ, Lande US, Wam HK (2015) Associational relationships at multiple spatial scales affect forest damage by moose. For Ecol Manag 348:97-107. doi:10.1016/j. foreco.2015.03.045

Hofmann RR (1989) Evolutionary steps of ecophysiological adaptation and diversification of ruminants - a comparatice view of their digestive system. Oecologia 78:443-457

Keunen JE, Plaizier JC, Kyriazakis L, Duffield TF, Widowski TM, Lindinger MI, McBride BW (2002) Effects of a subacute ruminal acidosis model on the diet selection of dairy cows. J Dairy Sci 85: 3304-3313. doi:10.3168/jds.S0022-0302(02)74419-6

Kuijper DPJ (2011) Lack of natural control mechanisms increases wildlife-forestry conflict in managed temperate European forest systems. Eur J Forest Res 130:895-909. doi:10.1007/s10342-0110523-3

Kuijper DPJ, Cromsigt JPGM, Churski M, Adam B, Jedrzejewska B, Jędrzejewski W (2009) Do ungulates preferentially feed in forest gaps in European temperate forest? For Ecol Manag 258:1528 1535. doi:10.1016/j.foreco.2009.07.010

Kuuluvainen T (2009) Forest management and biodiversity conservation based on natural ecosystem dynamics in northern Europe: the complexity challenge. Ambio 38:309-315

Lidskog R, Sjödin D (2014) Why do forest owners fail to heed warnings? Conflicting risk evaluations made by the Swedish forest agency and forest owners. Scand J Forest Res 29:275-282

Lindbladh M, Axelsson A-L, Hultberg T, Brunet J, Felton A (2014) From broadleaves to spruce - the borealization of southern Sweden. Scand J Forest Res 29:686-696. doi:10.1080/02827581.2014.960893

M.V.M (2005) The Merck Veterinary Manual. MERCK \& CO., INC. http://www.merckvetmanual.com $/ \mathrm{mvm} /$. Accessed 15 March 2013

Malmsten A, Dalin AM, Pettersson A (2015) Caries, periodontal disease, supernumerary teeth and other dental disorders in Swedish wild boar (Sus scrofa). J Comp Pathol 153:50-57. doi:10.1016/j. jepa.2015.04.003

Månsson J (2007) Moose management and browsing dynamics in boreal forest. Swedish University of Agricultural Sciences

Mansson J, Kalen C, Kjellander P, Andren H, Smith H (2007) Quantitative estimates of tree species selectivity by moose (Alces alces) in a forest landscape. Scand J Forest Res 22:407-414. doi:10.1080/02827580701515023 
Månsson J, Kalen C, Kjellander P, Andren H, Smith H (2007) Quantitative estimates of tree species selectivity by moose (Alces alces) in a forest landscape. Scand J Forest Res 22:407-414. doi:10.1080/02827580701515023

Mathisen KM, Milner JM, van Beest FM, Skarpe C (2014) Long-term effects of supplementary feeding of moose on browsing impact at a landscape scale. For Ecol Manag 314:104-111. doi:10.1016/j. foreco.2013.11.037

Mathisen KM, Pedersen S, Nilsen EB, Skarpe C (2012) Contrasting responses of two passerine bird species to moose browsing. Eur J Wildlife Res 58:535-547. doi:10.1007/s10344-011-0601-3

Mathisen KM, Skarpe C (2011) Cascading effects of moose (Alces alces) management on birds. Ecol Res 26:563-574. doi:10.1007/s11284011-0815-6

Mayntz D, Nielsen VH, Sorensen A, Toft S, Raubenheimer D, Hejlesen C, Simpson SJ (2009) Balancing of protein and lipid intake by a mammalian carnivore, the mink, Mustela vison. Anim Behav 77: 349-355. doi:10.1016/j.anbehav.2008.09.036

Milner JM, Van Beest FM, Schmidt KT, Brook RK, Storaas T (2014) To feed or not to feed? Evidence of the intended and unintended effects of feeding wild ungulates. J Wildlife Manage 78:1322-1334. doi:10.1002/jwmg.798

Milner JM, van Beest FM, Storaas T (2013) Boom and bust of a moose population: a call for integrated forest management. Eur J Forest Res 132:959-967. doi:10.1007/s10342-013-0727-9

Miranda M et al (2015) Ecological effects of game management: does supplemental feeding affect herbivory pressure on native vegetation? Wildlife Res 42:353-361. doi:10.1071/wr15025

Mueller DWH, Lackey LB, Streich WJ, Fickel J, Hatt J-M, Clauss M (2011) Mating system, feeding type and ex situ conservation effort determine life expectancy in captive ruminants. P R Soc B 278: 2076-2080. doi:10.1098/rspb.2010.2275

Oldemeyer JL, Franzmann AW, Brundage AL, Arneson PD, Flynn A (1977) Browse quality and Kenai moose population. J Wildlife Manage 41:533-542. doi:10.2307/3800528

Orams MB (2002) Feeding wildlife as a tourism attraction: a review of issues and impacts. Tourism Manage 23:281-293. doi:10.1016/s0261-5177(01)00080-2

Otto PI (2013) Winter feeding site choice of ungulates in relation to food quality. Swedish University of Agricultural Sciences

Parsons AJ, Newman JA, Penning PD, Harvey A, Orr RJ (1994) Diet preference of sheep - effects of recent diet, physiological state and species abundance. J Anim Ecol 63:465-478. doi:10.2307/5563

Persson IL, Danell K, Bergstrom R (2005) Different moose densities and accompanied changes in tree morphology and browse production. Ecol Appl 15:1296-1305. doi:10.1890/04-0499

Provenza FD (1995) Postingestive feedback as an elementary determinant of food preference and intake in ruminants. J Range Manag 48: 2-17

Putman RJ, Staines BW (2004) Supplementary winter feeding of wild red deer Cervus elaphus in Europe and North America: justifications, feeding practice and effectiveness. Mammal Rev 34:285-306. doi:10.1111/j.1365-2907.2004.00044.x

Rea RV, Hjeljord O, Harkonen S (2014) Differential selection of North American and Scandinavian conifer browse by northwestern moose (Alces alces andersoni) in winter. Acta Theriol 59:353-360. doi:10.1007/s13364-013-0170-9

Regelin WL, Schwartz CC, Franzmann AW (1985) Seasonal energymetabolism of adult moose. J Wildlife Manage 49:388-393. doi: $10.2307 / 3801539$
Rinella MJ, Dean R, Vavra M, Parks CG (2012) Vegetation responses to supplemental winter feeding of elk in western Wyoming. West $\mathrm{N}$ Amer Naturalist 72:78-83

Robb GN, McDonald RA, Chamberlain DE, Bearhop S (2008) Food for thought: supplementary feeding as a driver of ecological change in avian populations. Front Ecol Environ 6: 476-484. doi:10.1890/060152

Rothman JM, Raubenheimer D, Chapman CA (2011) Nutritional geometry: gorillas prioritize non-protein energy while consuming surplus protein. Biol Letters 7:847-849. doi:10.1098/rsbl.2011.0321

Sahlsten J, Bunnefeld N, Månsson J, Ericsson G, Bergstrom R, Dettki H (2010) Can supplementary feeding be used to redistribute moose Alces alces? Wildlife Biol 16:85-92. doi:10.2981/08-085

Schmitz OJ (1990) Management implications of foraging theory - evaluating deer supplemental feeding. J Wildlife Manage 54:522-532. doi: $10.2307 / 3809345$

Schwartz CC, Hubbert ME, Franzmann AW (1988) Energy-requirements of adult moose for winter maintenance. J Wildlife Manage 52:26-33

SFA (2014) Statistical yearbook of forestry 2014, Official statistics of Sweden. Swedish Forest Agency, Jönköping

Shochat E, Robbins CT, Parish SM, Young PB, Stephenson TR, Tamayo A (1997) Nutritional investigations and management of captive moose. Zoo Biol 16:479-494

Simpson RJ, Raubenheimer D (2012) The nature of nutrition: a unifying framework from animal adaptation to human obesity. Princeton University Press, Princeton

Sorensen A, van Beest FM, Brook RK (2014) Impacts of wildlife baiting and supplemental feeding on infectious disease transmission risk: a synthesis of knowledge. Prev Vet Med 113:356-363. doi:10.1016/j. prevetmed.2013.11.010

SOU (2014) Bilaga 6 Utfodring och attityder till utfodring i Sverige. In: Vildsvin och viltskador - om utfodring, kameraövervakning och arrendatorers jakträtt: delbetänkande. ISBN: 978-91-38-24149-3 vol 2014:54.

Spörndly R (2003) Fodertabeller för idisslare. Instutitionen för husdjurens utfodring och vård, Sveriges lantbruksuniversitet

Timmons GR, Hewitt DG, Deyoung CA, Fulbright TE, Draeger DA (2010) Does supplemental feed increase selective foraging in a browsing ungulate? J Wildlife Manage 74:995-1002. doi:10.2193/2009-250

van Beest FM, Gundersen H, Mathisen KM, Milner JM, Skarpe C (2010a) Long-term browsing impact around diversionary feeding stations for moose in southern Norway. For Ecol Manag 259: 1900-1911. doi:10.1016/j.foreco.2010.02.002

van Beest FM, Loe LE, Mysterud A, Milner JM (2010b) Comparative space use and habitat selection of moose around feeding stations. J Wildlife Manage 74:219-227. doi:10.2193/2009-109

Wam HK, Bunnefeld N, Clark N, Hofstad O (in press) Conflicting interests of ecosystem services: multi-criteria modelling and indirect evaluation of trade-offs between monetary and non-monetary measures. Ecosystem Services. doi:10.1016/j.ecoser.2016.10.003

Wam HK, Histöl T, Nybakken L, Solberg EJ, Hjeljord O (2016) Transient nutritional peak in browse foliage after forest clearing advocates cohort management of ungulates. Basic Appl Ecol 17:252-261

Wam HK, Hjeljord O (2010) Moose summer and winter diets along a large scale gradient of forage availability in southern Norway. Eur J Wildlife Res 56:745-755. doi:10.1007/s10344-010-0370-4

Westoby M (1974) Analysis of diet selection by large generalist herbivores. Amer Naturalist 108:290-304 